\title{
From paradigm to paradox - contemporary mainstream theoretical reflections for fieldwork in lowland South America ${ }^{1}$
}

\section{About the Nature and Culture divide and its implications}

Certainly, the selected authors agree with one argument, namely that the pres-
ent concept of culture in anthropology is already tributary to present scien-
tific assumption of the existence of "Nature." They recognize that the division
between the natural and human sciences has already been derived from a scien-
tific epistemology, previously a presupposition, that fundamentally distinguishes
the "real" world, immanent with its material existence independent of humans,

\footnotetext{
${ }^{1}$ Here I made a brief selection of articles and strived for a more dialectic exegesis of the ideas within the debate. Starting from the paradigm based on a dualistic apprehension of reality to the recognition of a paradox which may be turned into paradigm, I intended to pose questions on theory, ethnographic experience and epistemology of science. The debate on perspectivism and the ontological turn has occupied center stage in anthropology, animating such wonderful dialogues on the matter in many directions. For example, further evaluation and elaboration on the topic has been made by Graeber (2015). Graeber's account is brilliant, but it is focused in the idea of ontological turn considering the social political proposition attributed to it, as well as its relation to the analysis of ethnographic data. He brings up Critical Realists and Roy Bhaskar to advocate a reality possible beyond cultural meanings, favouring an "ontological realism". There are also two well written pages in Anthropology Today, where Bruno Latour (2009) briefly pointed out the theoretical similarities and divergences of ideas of Viveiros de Castro and Philippe Descola, based on a meeting held in the Institute of Advanced Studies, Paris. I do not present my own ethnographical research, simply because I intended to raise theoretical questions with the mainstream authors of previous ethnographic studies.
} 
from the one in which human action prevails. Nature is surely our origin, we are animated beings, like many others, and through the process of understanding our surroundings we develop an idea, now somewhat inadequate, that "a human being invents" his or her own reality, and that this invention is culture.

It is interesting to recall that the concept of culture and the notion of "anatomically modern human" were the foundations of the theoretical constructions that opposed evolutionism and racial theory. Our different developments are the result of cultural processes whereby biological differences are of little relevance. The "human being" would be biologically similar everywhere, the differentiation is precisely based on the inventiveness of groups in their expressions as human, universal in nature, differentiable by culture.

We are all members of the subspecies Homo sapiens sapiens, naturally identical, culturally different. Although this nature-culture opposition is significant, some authors point out that even in 'Western thinking' nature and culture can not be reduced to a single dichotomy (Strathern 2014). It is the dual treatment of some fields of Western society and the nature of anthropological knowledge questioning the foundations of human ideas that lead us to reflect on the role of this aspect of scientific thought.

Ingold $(2000 \mathrm{~b})$ emphasizes the implications of this conceptual fission by comparing walking with riding a bicycle. Cycling is something that results from cultural learning, whereas walking would be something innate to the human being. Characteristics that define us as an anatomically modern human being, such as bipedalism or language, are considered to be innate, but in fact, in order to walk or speak, human beings require intensive social interactions, through processes of acquired learning identical to that of riding a bike. By theory, capacity for language and bipedalism are biological characteristics that emerge spontaneously and structure themselves according to development. The environment in which development takes place would be responsible for particular variations in the manifestation of linguistic ability. For Ingold, one of the problems with such a proposal is that this model disregards the fact that a fetus since the initial formation already has the auditory organ developed and thus already apprehends sound environment.

The environment is not just variable circumstances for a pre-existing "mechanism of language". The environment is the context in which an individual develops both mechanisms and competence. "My point is that these capacities are neither internally prespecified nor externally imposed, but arise within processes of development, the properties of dynamic self-organization of the total field of relationships in which a person's life unfolds." (Ingold 2000: 399). So, like us, the "anatomically modern" Cro-Magnon needed to get along with his peers to learn key skills, and would certainly not have learned these skills by him/herself and made him/herself human through a solitary process.

Such learning was well exemplified in François Truffaut's movie, L'enfant Sauvage. In the film, a child of twelve is found in the forest eating roots and fruits, walking with his hands and feet, making grunts, with his actions mostly guided 
by his olfactory system and palate, and unable to communicate in complex ways other than gestures and reactions. The explanation given in the film is that having spent a long period of time without socializing with society his cognitive and psychomotor development had been limited, due to the lack of stimulae in the phases of ability acquisitions. Although Victor, the protagonist, learns many things with the doctor, some difficulties seem to be irreversible. The story is not totally fictional, but is based on true facts reported in a book by a medical psychiatrist Jean Itard. The 'human being', as far as we can see, exists only in contexts of coexistence with other humans, who also lead their lives among other humans and so forth. The idea of an anatomically modern human is certainly tributary of the divide between nature and culture in studies of human development. In this sense, Nelson Rodrigues' statement that "the human being, as we imagine it, does not exist" (cited in Viveiros de Castro 2002, p.1) can be interpreted as recognition that we only exist contextually, therefore, being "human" is an interpretative schema of the West based on assumptions rooted in science. Its current use and common sense meaning are evidence of its ontological dimension. The process of living and learning certainly leaves traces in the anatomy and creates cultural conditioning that directly and indirectly influences an individual. To regard certain abilities as innate is to isolate them from the historical processes by which they emerge, and it is contrary to the dynamics of human development.

Thus, walking cannot be natural, while pedaling is considered to be something cultural, since both only happen through learning and in particular social circumstances. The same goes for the capacity for language. Speaking cannot be inborn, while writing is a result of culture, since in both there is a need for specific conditions for them to flourish. In this way, Ingold comes to the conclusion that the concept of an anatomically modern man is inefficient. Human beings, like all other life forms, are constantly changing. The human being is biologically a constant becoming intrinsically linked to its environment through development. The result of this change, for Ingold (2011: 7) is:

to invalidate once and for all the deep-seated assumption that the differences of language, body posture, and so forth, which we are inclined to call cultural, are superimposed on a pre-constituted substrate of human biological universals. We can no longer be satisfied with the superficial notion that all human beings begin (biologically) equal and end (culturally) very different. Consider, for example, this formulation of Geertz: "One of the most significant facts about us may be that we all begin with the natural equipment to live thousands of species of lives, but we end up living only one species" (1973: 45). My argument, against Geertz, is that human beings are not naturally pre-equipped for any kind of life; instead, the equipment they possess becomes, through a process of development, as they live their lives.

Accepting Geertz statement implies an idealized understanding that after attaining the anatomically modern state of human, human evolution is, in some 
way, replaced by history, and at this point the boundary separating studies from the natural sciences from the studies of the human sciences is evident.

This separation was also emphasized by Descola (2011) who, observing the organization of a Natural History Museum, realized that in the grouping of objects, the spatial organization of the museum is conceived in accordance with the dualistic nature/culture scheme, which he uses to reevaluate these aspects in contemporary science.

The proposal of process and movement is present in other reflections of Ingold, reaffirming the uninterrupted flux of existence for an anthropological approach. Bringing art to the table, the author refers to Paul Klee's concept:

The processes of genesis and growth that produce the forms we find in the world we inhabit are more important than the forms themselves. "Form is the end, death," he wrote; "Shaping is movement, action. Shaping is life" (1973, see Ingold 2012: 26).

The form of the human being is neither definitive nor separable from the environment in which s/he lives, it is a continuous interaction between form and matter. Nature is not the brute state of things that is transformed by human action into cultural objects. It is concluded that the way humans evolve and develop their aptitudes is intrinsically related to the environment and is also a major concern for research focusing on "human" inter-relations with other beings, such as animals and plants. We will see that, in some systems of knowledge, these relations are often understood in terms of interactions of agents that mutually influence each other, that possess also humanity even though they are not "humans" in common Western sense.

Bringing together biology and culture, evolution, and history, Ingold takes away the centrality attributed to the human being as the transforming agent of nature in what we call history. The author states that history is a complex process of creative interactions between the human being and his or her circumstances. "History is the process in which men and their environments are at the same time and continually in formation, each in relation to the other" (Ingold 2006: 34).

\section{"We study culture through culture"}

One of the greatest works that addresses the concept of culture in contemporary anthropological thought is Wagner's (1975) The Invention of Culture, particularly the first three chapters. The relativization of anthropological analysis, through the recognition that anthropology itself is culturally made, calls into question the construction of the veracity of anthropological knowledge regarding how analyses and generalizations are themselves already culturally circumscribed.

Culture is the anthropologist's point of view and goal, and for Wagner anthropologists must abdicate from the alleged absolute objectivity to a relative 
objectivity, in which they recognize their own culture in the construction of knowledge. "The implication of the idea of culture, the fact that we belong to a culture (relative objectivity), and that we must assume all cultures to be equivalent (cultural relativity), leads to the general proposition concerning the study of culture" (Wagner 1975: 3).

Culture is the point of convergence between researcher and researched through the understanding that each human group is similar to the other, because they are groups that produce culture, or, as previously stated, naturally identical although culturally different. For Wagner, anthropological knowledge is a dialogical process of understanding, in which the analyzed culture and cultural agents are amalgamated in the ethnographic text. The anthropologist must leave the boundaries of his or her own conventions and question them in the face of ethnographic data. For this to happen, the anthropologists need to simultaneously be aware of their own culture and his or her interlocutors' culture, and therefore, since culture is studied by culture, the result of the research is more like an invented culture. Invented according to the anthropologists' own anthropological expectations of what culture is, the departments and lines of their own researche and the circumstances and problems encountered by the anthropologist in the field.

The study of anthropology is culture, and if the anthropology that wishes to be aware, and to develop its sense of relative objectivity, must come to this fact. The study of culture is in fact our culture; it operates through our forms, creates in our terms, borrows our words and concepts for its meanings, and re-creates us through our efforts (Wagner 1975: 16).

We can note that in common-sense meaning there is generally a distinction between culture as particular symbolic manifestations of a historically circumscribed people, and culture as an ideal of human refinement, the material transformation nature in a cumulative process. Anthropological studies have mostly shared their results among the academic community in a way that does not complicate the study of culture, and neglects the imposition of our own preconceptions on other peoples (Wagner 1975: 23). Wagner wonders what are systems of kinship, buying wives or witchcraft if not reflective conceptual impositions of ours? In the act of inventing another culture, the anthropologists invent their own, and in fact he or she reinvents the notion of culture itself (Wagner 1975: 4).

The recognition that culture is historically circumscribed does not mean to deny that other peoples do make significant distinctions between their creations and understandings of a domain that is, in a really simple translation, the reality that surrounds them. Wagner proposes that the main characteristics of cultures are not their cohesion, their adaptability to a medium or even their set of understandings. The "salient characteristics of culture" are convention and invention, the foundation of the dynamics between reproduction and renewal of cultural forms (Wagner 1975: 42). This dynamic process seems to me to be something 
similar to Gregory Bateson's spiral in his Mind and Nature (1986). It is seen as a figure that holds its shape (that is, its proportions) as it grows into a dimension through addition on the side that is open. Here, we still have the processual character emphasized by Ingold in the relations of culture and history.

Referring to Charles Peirce's notion of symbols, Wagner said that symbols are non-static conventions that coexist with process of interaction with specific contexts of living. Symbols are alive and denote something more than themselves (1975: 42); they are conventions that innovate in perpetual processes of transformations, where convention subsists in the process of reinvention, and whereby innovation takes shape in the premises of the convention.

As a dialectical process of constructing meanings, culture exists in individuals and their motivations and relations as much as within new events and situations. Cultural transformations would arise from combinations of the context and the symbolic faculty, that through metaphor and analogies individuals articulate with meanings within new contexts. Innovation is internal to the process of conserving meanings, and at the same time enlarges, modifies and conserves them. The convention mediates innovation in emerging symbolic contexts, so that these processes are necessarily simultaneous and reciprocal.

The need for invention is given by cultural conventions. In Wagner's words "Every use of a symbolic element is an innovative extension of the association that acquires it through its conventional integration into other contexts" (Wagner 1975: 39). From this axiomatic statement one can conclude that meaning exists from its relations, contextually and historically circumscribed, and thus, the search for an absolute meaning is destined to fail.

Wagner's ethnography among the Daribi led him to propose that among them, what we can understand as culture or collective conventions of social life are given by humanity and the universe. Wagner proposed that among the Daribi there is no "culture" as a result of learning and accumulation of knowledge, or as a human transformation of nature. These propositions have influenced the work of Marilyn Strathern, Viveiros de Castro and Philippe Descola, who, when addressing indigenous cosmologies of New Guinea and America, emphasized that these peoples express different understandings about nature and culture which point to other ways of perceiving relationships with the environment.

\section{Rethinking nature and culture}

The main argument of Marilyn Strathern, Viveiros de Castro and Philippe Descola is that other people may develop other definitions equivalent to nature and culture, but that does not mean that they subsume the same contents or even have the same social relevance as in western thought. Without proper reflection, the categories of nature and culture can be transposed to natives and used by some anthropologists as if they were inherent in human conceptualization, from the inference of the "real." All three authors consider anthropological knowledge 
to be circumstantial to its historical and cultural developments. The exegesis of native cosmologies would be incomplete and ethnocentric in a negative sense. It is necessary to personally question the assumptions upon which anthropology developed, particularly when living among others in a different style of life seems to be the main source for rethinking relations.

As Descola and other authors point out, if in the West, when we refer to our difference from the animal kingdom we speak in terms of cultural differentiation, by learning and manipulating the world in a way that is proper to the human being, we do not find the same parallel among Amerindians. In their animal and plant cosmogonies, they were once undifferentiated from humans (in appearance) and thus communicated with each other. Things such as fire, agriculture, ceramics and weapons were given or stolen by humans from other animals in the distant past.

For us, it is at least unusual to think of the origin of so-called "cultural" elements coming from species other than our own. In many cosmological narratives the speciation of beings has led to differentiation in their physical appearance. However, the qualities of being intentional agents who experience the world and live under social rules, performing rites, practicing shamanism, were preserved by some animals. Hence, there is a common place recurrence of statements by natives that the appearance of animals is like clothing and that inwardly they are "like us" or are "human." On this basis, Descola (2011: 45) states that:

Amerindian myths thus do not evoke the irreversible passage from nature to culture, but rather the emergence of natural "discontinuities" from a cultural "continuum of origin, within which humans and nonhumans were not distinguished with clarity".

In referring to the concept of animism, Descola recalls its difference to totemism. Totemism is based in the differentiated characteristics of other forms of life that serve as examples for the organization of social life. It operates by metaphorical analogy, so that the highlighted qualities are taken to delineate the social order. The specificities of a totemic group are defined by identifiable similarities between the group and the referent, whereby continuity is established by denotation. Animism differs from totemism because it does not deal with the extension of other animal characteristics to humans, but with the existence of a socio-morphic similarity between humans and other species that are differentiated by physicality. Animism conceptualizes an experienced world of relations of exchange and coexistence with other species, and encounters even with their own "human forms", as in the experiences of subjectification in shamanism. The result is the idea of humanity as a common condition of the species in question.

Beings are organized in collectivities by institutions and ways of life similar to the humans, these being differentiated in expression due to their bodily differences. According to Descola, this worldview is not representative of "minorities", 
since it is identifiable in the Americas, Liberia and Southeast Asia (2015: 88). Certainly, animism is distinguished from other worldviews also by placing humans in relation to these animals in their "human" forms, furtive encounters in the forest, in dreams and by shamanic techniques that allow one to see other beings in their human form.

The axis of analysis of these cosmologies is evidently what is understood as an Eurocentric ontological aspect transformed with the scientific revolutions in an evolutionary naturalism. As such, nature is supposed to be a common domain between humans and other beings, in the sense that we are living expressions of a common material universe, we are biologically constituted of the same substrate. However, we humans differentiate ourselves by living in culture, and that serves to justify humans as unique to all expressions of life. In the Amerindian context, however, what we call nature is already populated by a multiplicity of individuals, subjects that interact by co-creating nature.

In Viveiros de Castro's perspectivism, the main objective was to delineate an essential aspect of a relational form between humans and nonhumans that is recurrent in the Amazonian context and, according to the author of the concept, applicable in some cases to the Pan-Amerindian context. Ethnographies tend to show that this relation plays a central role in the indigenous cosmological/ ontological axis, guiding the way of perceiving oneself and other beings.

Returning to what has already been said, in the so-called Eurocentric view, what essentially defines the distinction between human beings and other animals is humanity, understood as the sociocultural construction of reality. In the West, the similarity between humans and animals is physical, we are animals, but different. For Amerindians, according to Viveiros de Castro, humanity is the characteristic shared by both, the difference is actually is in the physical form. So far, perspectivism is identical with animism. What perspectivism adds is fundamentally the relational character of this reality, pointing to the ways in which particular beings perceive the world and therefore interact in it. It is from the following definition of animism that Viveiros de Castro (2002: 361-362) affirms the differences of perspectivism;

The "elementary categories of social life" organize the relations between humans and natural species, thus defining a sociomorphic continuity between nature and culture, based on the attribution of "human dispositions and social characteristics to natural beings".

This definition of animism presupposes an extension of social relations to the non-human realm, and in a Lévi-Straussian analysis, they oppose the "naturalistic" model in which human and non-human relations are only natural, by sharing a biome and the same biological needs. However, according to Viveiros de Castro, this definition of animism presupposes that non-human sociality can be interpreted as a projection of human sociality in the animal world, thus being anthropocentric and ethnocentric. Perspectivism proposes that 
humanity extended to animals is not a mere projection of human society, but part of the ontological rooting of indigenous thought, where "culture" is a characteristic of the nature of beings. Moreover, perspectivism precisely adds the problematic of "perspectives" in inter-species encounters bringing reflections to the body as a differentiating point.

Viveiros de Castro proposes that while multiculturalism affirms a unity of nature through an objective universality of bodies with differences in cultures and meaning, indigenous multinaturalism affirms a unity of spirit and diversity of bodies. Hence we are equal to other animals in inwardness, beings who see themselves and act as subjects in the world and differ in nature. It is mainly a question of differentiation of bodies.

It is clear that perspectivism is not a kind of relativism, whereby each being-subject is endowed with a representation of the "real". In his evaluation of the various Amerindian ethnographies, Eduardo Viveiros de Castro states that the way of representing the world is only one. This means that non-humans do the "same" as humans, hunt, fish, have chiefs, ritual houses, kinship relationships, etc. It is not through the way the subject sees that he or she is inseparable from his or her "body," for every subject will have its group ruled by similar "institutions", what changes is precisely what each being represents in the another's point of view. This quality of perspective rarely extends to all species. It is aimed at animals with closer ties to the indigenous community, large predators, such as the jaguar, typical prey, such as some species of fish and game, and supernatural entities. These beings are often in a relationship with the human from their mythical origins, often playing the role of "owners" and connoisseurs of so-called "cultural" instruments essential to the current social life of human beings.

The first volume of Lévi-Strauss Mythologiques (2010) already exemplifies what is under debate. In the Kayapó, Timbira, Xerente and Apinayé myths about the origin of fire it is the jaguar who "knows" the bow and the fire, at the time when the humans did not use such instruments. Stealing or receiving them as a gift, humans learn such techniques with the jaguar who, in the various versions of the myth and at different times, communicates with the man in a friendly or aggressive manner. Their mythological roots place two fundamental elements of the predatory complex, the bow and the fire, not as the result of human creation, but rather as the result of encounters with this great predator and other animals that share the same environment.

Considering such relations and working among the Juruna, Tânia Stolze Lima (1996) points out that in the mythical sphere, there are common stories in which the boars become human and share moments with the Juruna when they drink cauim (fermented manioc brew) and smoke tobacco. The shaman could communicate with the boars' shaman and establish a bond, somehow also ensuring good hunting. According to Lima, in the relational scope of human-animal-supernatural entities, what exists is not a single event or things perceived by different points of view, but rather two different events, because the subjects are of different bodies. 
All beings "see" the world in the same way, what varies is the world they see because they inhabit different bodies/perspectives. What is blood to us is the cauim of the jaguar, the leaves of the cotton, the "salmon" of the salmon, which in turn "sees" itself as human. In Lima, it is stated that a shaman peccary is initiated into shamanism by a human and a human one is initiated by spirits, that is: in the shamanic universe, humans can represent for peccaries what spirits represent for humans. The issue of relational representations, such as the above example, reasserts a hierarchical aspect of these relations, particularly between prey and predator, changing positions depending on how the encounters occur, and which define the actions of subjects in relation to others.

Eduardo Kohn (2013) in the introduction of his book How Forests Think, recalling a night at the hunting camp recounts; “Sleep face up! If a jaguar comes, he'll see you and you can look back at him and he will not bother you. If you sleep face down, he'll think you're aikha (prey; lit., "meat" in quichua) and he'll attack". Juanicu was saying that if the jaguar is capable of looking back - at a self like himself, in you - he will leave you alone. But if the person is representing an it, he/she might as well become dead meat (2013: 1). This kind of "pronominal" relation between species and the understanding of relational points of view is something that perspectivism certainly adds to the concept of Descola's animism. My intention in using these arguments here is to exemplify the connections between ontological premises and the types of relations that are established with other species in daily life, what directly relates to processes of always becoming beings, of existing in relation.

Another example, one from the other side of the world, is captured in the reflections of Strathern (2014) inspired by Wagner's work, specifically aimed to elaborate the notions of "nature" and "culture" of Hagen society, and evaluate the ethnological material that engaged these concepts to understand reality and gender relations through the dualism between the domestic ( $\mathrm{mbo}$ ) and the wild (romi). According to Strathern "among all the meanings that nature and culture have in the Western world, certain systematic selections are made when the same ideas are attributed to other peoples" (2014: 25). In the Hagen case, the relationship between ecology and society spelled through the notion of environmental control and the oppositions between biology and the anthropic in the formation of gender ideas are not exactly correlated with the ideas of the wild and domestic domain. Opposition between the fields is something that is increasingly revealed as belonging to the West, in which culture is nomos and tékne, nature is the given world, which precedes and succeeds us and which we manipulate.

This overlapping of our thinking models on indigenous peoples, which at first sight seem to be present in their organization and symbolism of dichotomous divisions, leads to an anthropology that only seeks parallel, but is based on universal human development, given that universality is attributed to parameters for symbolization that when detailed analyzed are distinct. The very difference between the individual and society can be treated in this way by placing the individual alongside nature, a human nature that is brought up by culture, its 
"impulses" and "natural" forces that are modeled by living with the collectivities. In this game of ideas, it is necessary to clarify in detail, to exhaust the explanatory possibilities and exemplary or atypical situations in which such oppositions and dichotomies arise, since, as Strathern proposed, nature and culture can not be reduced to a single dichotomy even in Western thought.

It is with this understanding, and based on ethnological material that Strathern states that our uses of male and female in gender relations reproduces a dichotomous sense. "They represent an entity (the human species) divided into two halves, so that each is defined by what the other is not" (2014: 33). The author formulates a critique of Ortner's work, particularly her claim that women would be closer to the realm of nature by bringing data where the man-society and woman-nature model contradict each other. Furthermore, Strathern (2014: 43) recalls Wagner's work and the Daribi conceptions about these domains, to establish that among the Hagen the distinction between domestic and wild is considered innate, and not a creation of our ideas about reality.

Among the Daribi, the contrast between the innate and the artificial in the processes of particularization and collectivization occupies a different position from that of Western culture. Thus, the collective conventions of Daribi social life are considered given components of humanity and the universe, in which individuals improvise, differentiate and particularize themselves, while "we" emphasize the collectivization of controls that have to constantly act on individualizing and innate motivations. For the Daribi, there is no "culture" in the sense of artifacts and rules that represent a sum of individual efforts, nor a "nature" from which these elements would be formed.

By manipulating wild extra-social forms, men can influence the growth of domestic domains, and that already reveals an internal contradiction to a systematic opposition between these domains. This ability is considered just as innate as women's capacity to beget children. The child as an individual is considered $m b o$, eats domesticated foods, and grows in a community; what leads Strathern to understand the notion of culture as a way to humanize the individual certainly makes no sense among the Hagen.

The author cites the example of the opening of Hagens' gardens, when Hagens seek to reach agreement with the wild, not only through the manipulation and control of it. Strathern concludes that the romi can be understood as a category of power located outside the realm of creation and control, and thus a parallel between our conceptions and those of the Hagen is not possible. Mbo maintains an association with the act of planting and caring, with the distinction between the environment which humans and animals inhabit. For Strathern, the way the Hagen distinguish themselves from other human groups resembles our ways of defining culture. What certainly can not be transposed is the implicit sense of relations between nature and culture in the sense of manipulation, or even that a culture has a substratum of the so-called nature. 
Ortner's homology between the domestic-nature and the cultural-public, supported by the argument that these oppositions "reflect a universal consciousness of domestic life as infra-social" (2014: 56) are reconsidered by Strathern. Strathern's ethnographic examples seek to demonstrate how, in certain contexts, the associations within these parameters are unsustainable, because men at certain times are associated with the domain of the wild-nature, and women with domestic-culture. She states that this is also true for the Eurocentric thought itself. Women in legends are associated with cultural goods, fire, handcrafts, and cooking; while men by the exercise of magic, recognized as an mbo domain, produce the crops, the pigs. With gender issues we can not fall into a reductionism that fits into oppositions as social-non-social or culture-nature. As Strathern (2014: 74) says:

Our own concepts provide such a convincing structure that when we come across other cultures that relate, say, a male-female contrast to the oppositions between the domestic and the savage or between society and the individual, we imagine that they are part of the same whole.

In their respective work, Descola, Viveiros de Castro and Strathern exemplify the possibilities of exploring the distinctions between nature and culture not only for the production of anthropological knowledge, but for the very elucidation that our methods of observation are inscribed in particular epistemologies. Anthropology thus becomes a dialogical knowledge that, while elucidating the ways of being and thinking of other peoples, allows us to better know our own ways of thinking and being. Certainly, Hagen and Amerindian understandings teach us as much about them as they do about ourselves.

\section{Conclusions}

Of course, all the references here have been used in order to reveal how much the production of knowledge is inscribed in its cultural developments. The separation between the natural and human sciences is, certainly, only one facet of our peculiar way of making inferences about the real from dual distinctions between a world of materiality and spirit, human action and nature, biology and the symbolic. That is the first step.

Anthropology is culture, and anthropologists recall that its capacity for analysis derives, ultimately, from the construction on a comparative basis to answer what defines humanity. Of course, the dialogical processes of constructing anthropological knowledge through ethnographic research reveal different meanings than ours, from which we question our own understandings. The ethnographies of Descola, Viveiros de Castro and Strathern show how, among other peoples, there is no parallel to our conceptions of nature and culture.

Amerindians seem not to look at the forest as the environment in which they as humans transform it into a culture, but as an environment inhabited by beings who see themselves in the world as subjects who learn and live culture through 
their bodies. We can question intellectually and in practice the relationships that we develop with the environment in cultures whose interactions with other species view them as distinct agents that in their own interactions with us experience the same processes of formation and existence. Surely the forest would be a very different place if there were not, since times immemorial, the jaguar, anaconda, peccaries and "humans".

The theoretical proposals of Ingoldtake the same direction toward a world of multiple agencies, where human is one among others. Giving agency to the world may reinforce an understanding that symbolic is actually a dialogical process whereby humans, other beings and environments exist simultaneously and are in continuous formation, each in relation to the other. Concurrent with questioning of the bases of the production of knowledge from an epistemology of science, we create the possibility to rethink the relations between humans and nonhumans toward a less anthropocentric description of culture.

\section{References}

Bateson, G. (1986). Mente e Natureza - A Unidade Necessária. Rio de Janeiro: Francisco Alves. Descola, P. (2011). As duas naturezas de Lévi-Strauss. Sociologia \& Antropologia, v.01.02: 35-51, http://www.ppgsa.ifcs.ufrj.br/evento/revista-sociologia-antropologia/.

Descola, P. (n/d). Más allá de la naturaleza y la cultura. Cultura y Naturaleza. Jardín Botánico de Bogotá José Celestino Mutis. Avaliable in: http://ecaths1.s3.amazonaws. com/teoriasocialcontemporanea/578647752.Descola\%20mas\%20alla\%20de\%20la\%20 naturaleza...pdf.

Graeber, D. (2015). Radical alterity is just another way of saying "reality". A reply to Eduardo Viveiros de Castro. Hau: Journal of Ethnographic Theory, 5(2).

Ingold, T. (2000). The perception of the environment: Essays on livelihood, dwelling and skill. London: Routledge.

Ingold, T. (2000b). Gente como a gente: $\mathrm{O}$ conceito de homem anatomicamente moderno. Ponto Urbe. Edição 9, http://www.pontourbe.net/edicao9-traducoes/213-gente-como-a-gente-o-conceito-de-homem-anatomicamente-moderno.

Ingold, T. (2006). Sobre A Distinção Entre Evolução e História. Antropolítica, Rio de Janeiro, n. 20, 17-36, http://www.uff.br/antropolitica/revistasantropoliticas/revista_antropolitica_20.pdf.

Ingold, T. (2015). Introdução a O que é um animal? Antropolítica, Rio de Janeiro, 22, 129-150, www.uff.br/antropolitica/revistasantropoliticas/revista_antropolitica_22.pdf.

Ingold, T. (2012). Trazendo as coisas de volta à vida: Emaranhados criativos num mundo de materiais. Horizontes Antropológicos, Rio Grande do Sul, ano 18, n. 37, 25-44, jan./jun.

Kohn, E. (2013). How forests think: Toward an anthropology beyond the human. Berkeley: University of California Press.

Latour, B. (2009) Perspectivism: 'Type' or 'bomb'? Anthropology Today, Apr. vol 25 no. 2, 1-2. Lévi-Strauss, C. (2010). Mitológicas I: O cru e o cozido. São Paulo. Cosac \& Naify.

Lima, T.S. (1996). O dois e seu múltiplo: Reflexões sobre o perspectivismo em uma cosmologia tupi. MANA, Rio de Janeiro, vol. 2, n. 2, 21-47.

Strathern, M. (2014). In: O efeito etnográfico e outros ensaios. São Paulo: Cosac \& Naif.

Viveiros de Castro, E. (2002). A inconstância da alma selvagem. São Paulo, Cosac \& Naify. 
Viveiros de Castro, E. (2002). O Nativo Relativo. MANA 8(1):113-148.

Wagner, R. (1975). The Invention of Culture. Chicago: University of Chicago Press.

\section{SUMMARY}

From paradigm to paradox - contemporary mainstream theoretical reflections for fieldwork in lowland South America

This essay intends to address perspectives and reflections on nature and culture in the contemporary anthropological literature. Dialogically engaging with Ingold, Wagner, Viveiros de Castro, Descola and Strathern, I aim to demonstrate the implications of understanding culture as an axiomatic point of differentiation of human nature, or as re-elaboration of materiality through human action. This reflection calls us to rethink the Western scientific epistemology, along with its presupposed ontological order. Such questioning unfolds in the elaboration of the ethnographic text, which in turn is the result of a dialectical process that speaks not only of one culture, but of two, and especially of our gaze on the Other. In the ethnographic text, an anthropologist and a native are the potential locus of reproduction of their culture. Through this approach we extend the implications of epistemological concerns to fieldwork practices and to the art of understanding other knowledge systems.

Key words: epistemology, culture, perspectivism 